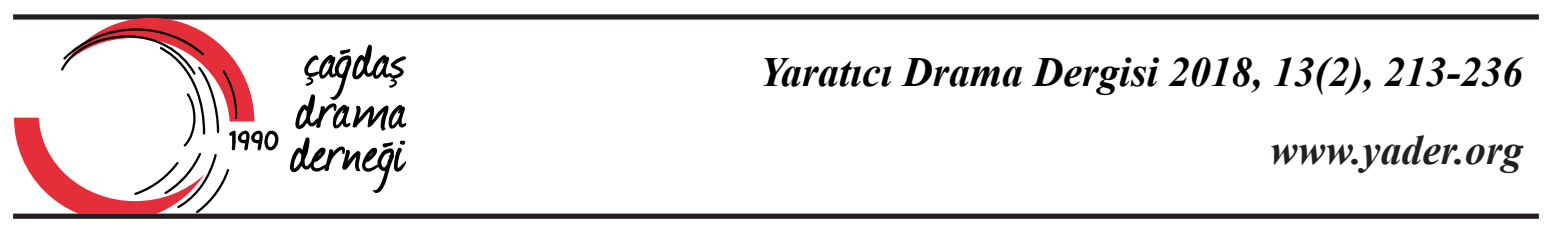

\title{
İnsan İlişkileri ve İletişim Dersinde Yaratıcı Drama Uygulamalarının Etkisine İlişkin Öğrenci Görüşleri
}

Mustafa Yeler ${ }^{1}$

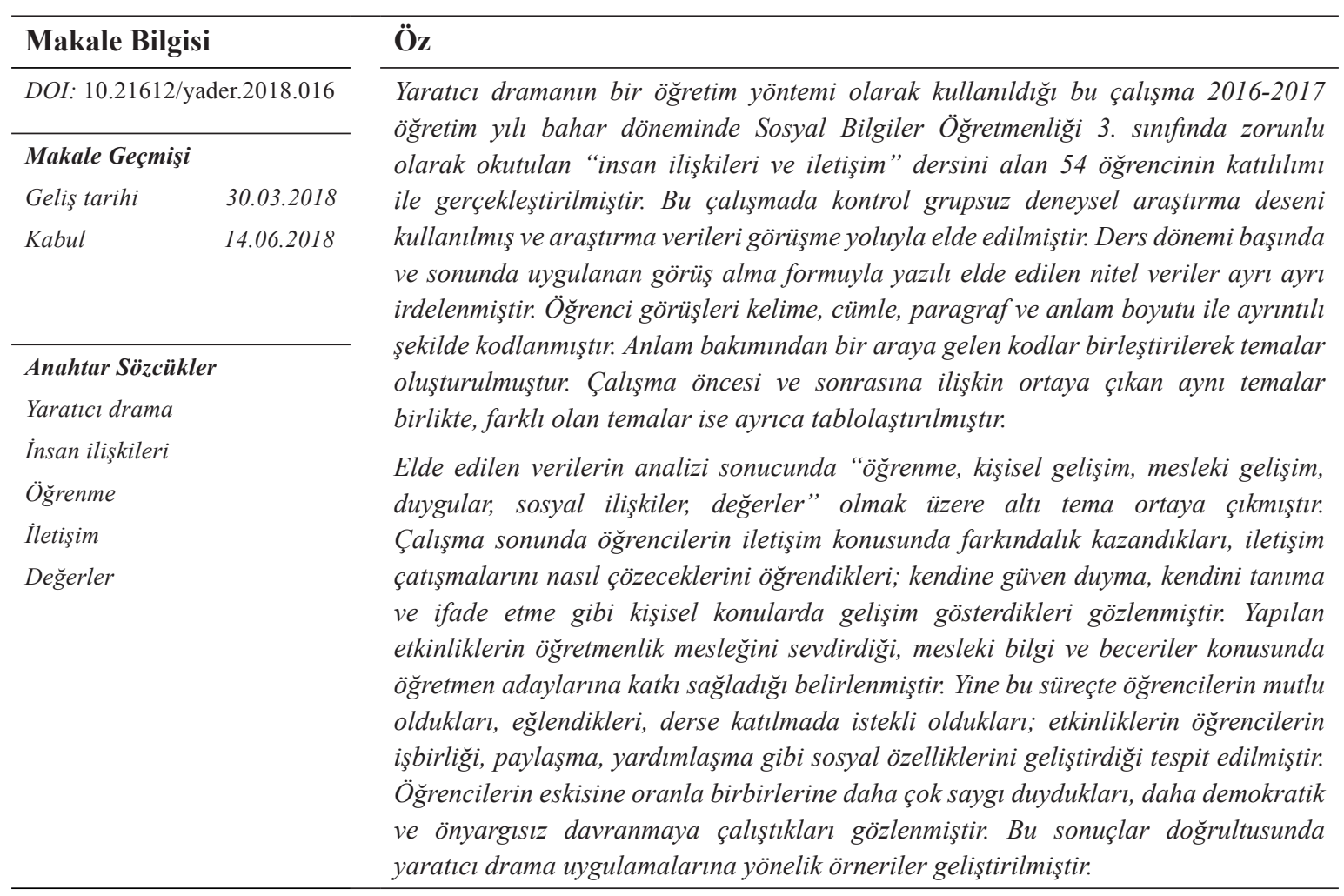

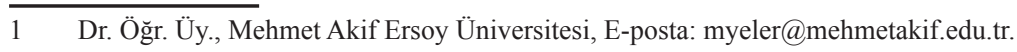




\section{Students' Views on the Effects of Creative Drama in Human Relationships and Communication Course}

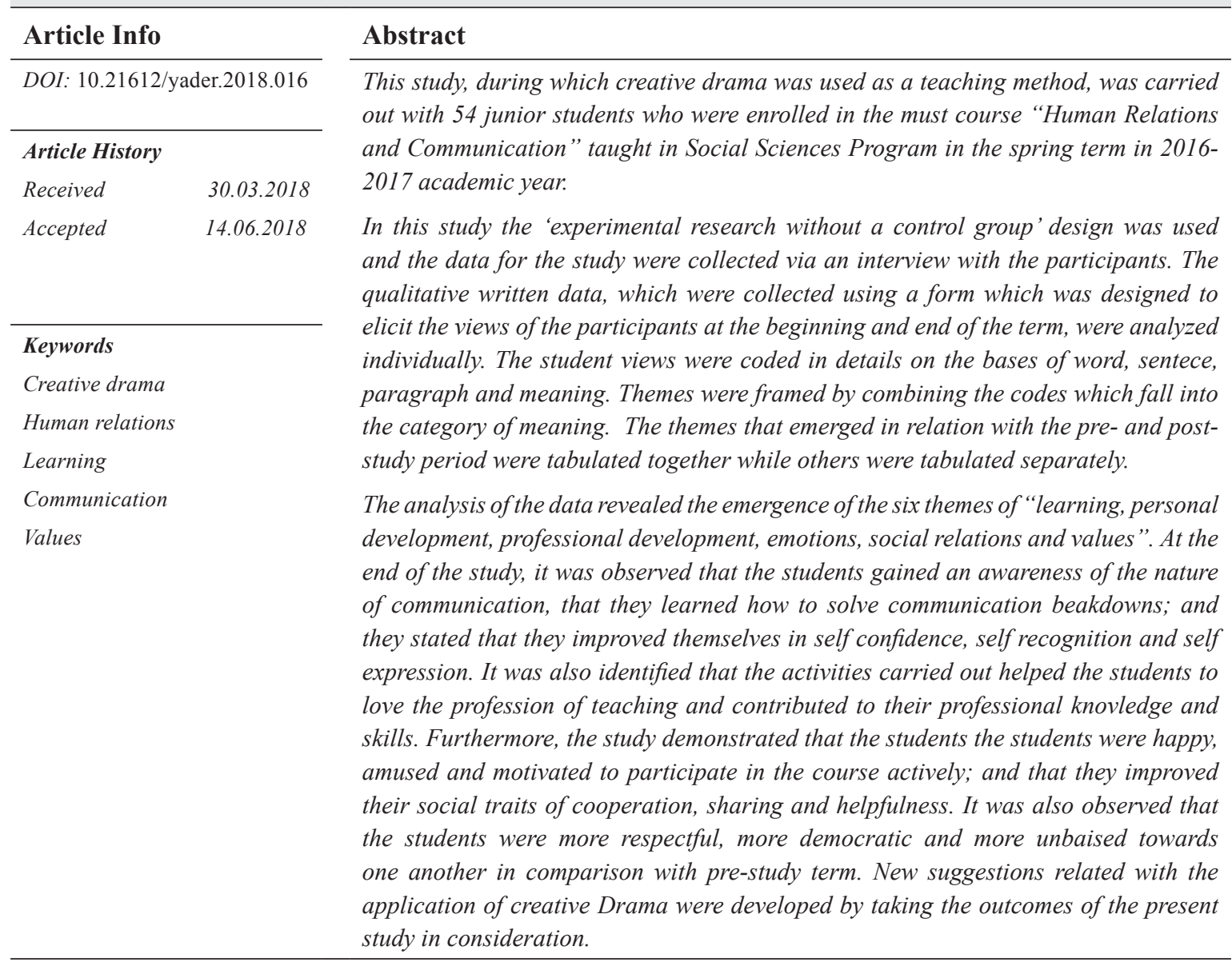




\section{Giriş}

İnsan, sosyal bir varlık olarak doğumundan ölümüne kadar olan süreyi toplum içinde yaşayarak geçirir. Bu sürecin verimliliği ve niteliği, kişinin toplum içindeki diğer insanlarla kurduğu iletişim ve etkileşime bağlıdır. Bu açıdan bakıldığında iletişim insan hayatında önemli bir yere sahiptir, bu doğrultuda iletişim "yaşamla iç içe” olarak nitelendirilebilir (Akoğuz, 2002) .

Türk Dil Kurumu (2009) sözlügüne göre, "duygu, düşünce ya da bilgilerin usa gelebilecek her türlü yolla başkalarına aktarılması” olarak tanımlanan iletişimin temel işlevini Yalın (2000) "anlamları ortak kılmanın yanı sıra duygu, düşünce, bilgi ve becerileri paylaşarak davranış değişikliği meydana getirmek" olarak vurgulamaktadır.

Öğretme-öğrenme sürecindeki yaşantılar açısından bakıldığında ise iletişim becerileri, öğretmenin mesleki ve kişisel özellikleri açısından da önemli bir yere sahiptir. Çünkü öğrenme süreci en genel anlamda bir iletişim sürecidir. Sınıf-içi iletişimin niteliği, öğrencilerin kişilik gelişimleri ve başarılarını etkileyen önemli bir unsurdur (Ergin ve Birol, 2000). Öğretme ve öğrenme süreçlerinde gerçekleştirilen tüm etkinlikler birer iletişim etkinliği olarak ele alındığında bu süreçlerin etkili olabilmesi için iletişim süreçlerinin de çok iyi planlanması ve uygulanması gerekmektir. Bu bağlamda söz konusu etkinlikler iletişimi artıracak işbirliğine dayalı öğrenme, drama, oyun vb. uygulamalarla yürütülebilir. Öğretme-öğrenme sürecinde iletişimi ve etkileşimi artıran en etkili öğretim yöntemlerden biri olarak yaratıcı drama ortaya çıkmaktadır. Çünkü Selimhocaoğlu (2004)'nun da belirttiği gibi yaratıcı drama da iletişim sanatlarından biri olarak düşünüldüğünde iletişim, dramanın hem amaçlarına ulaşmada bir amaç hem de tüm süreçlerinde yer alan bir kavramdır ve yaratıcı drama sürecine katılanlar için oldukça önemlidir. Başka bir ifade ile yaratıcı drama çalışmaları iletişim kurallarına da dayanır. Aynı zamanda bireylere iletişim becerilerinin kazandırılmasının gerekli ve önemlidir (Adıgüzel, 2013). Tüm bunlar düşünüldügünde yaratcı drama; “... bir grup çalışması içinde, bireylerin bir yaşantıyı, bir olayı, bir fikri, kimi zaman bir soyut kavramı ya da davranışı, eski bilişsel örüntülerin yeniden düzenlenmesi yoluyla gözlem, deneyim, duygu ve yaşantıların gözden geçirildiği süreçlerde anlamlandırması, canlandırması” olarak tanımlanmaktadır (San, 2006).

Bir başka deyişle yaratıcı drama eğitim sürecinde oyunlarla geliştirilen bir etkinlik olup bu özelliği ile eğitimin yaşamsal parçasıdır (Üstündağ, 1994). Drama etkinlikleri; bireylerin birbirleriyle etkileşim kurmalarını sağlayarak, bireyin grupla iletişimi, yaşantısını sürdürme, gruba ait olma ya da bir grubun üyesi olmanın getirdiği sorumluluk, iletişim ve problem çözme becerilerinin de gelişmesine katkıda bulunduğu gibi aynı zamanda bireylerin kendilerine güven ve saygı duymalarına da yardımcı olmaktadır (San,1990). Ayrıca yaratıcı drama sürecindeki bu etkinliklere katılım gösterildiğinde iletişim sürecinde önce kendi düşüncelerimizin, duygularımızın ve bedenimizin farkına varırız. Bir durum, olay ya da kişi karşısında neler düşündüğümüzü inceleme olanağı buluruz. Benzer biçimde bir durum, olay ya da kişi karşısında duygularımızın, tutumlarımızın, değer yargılarımızın, alışkanlıklarımızın vb. neler olduğunu gözlemleyebiliriz (Oğuz ve Altun, 2011). Bu ve benzeri sonuçların elde edilmesinde en önemli etken ise yaratıcı drama süreçlerinde öğrenilen bilgilerin her zaman yeni bir bakış açısıyla değerlendirilmesi, deneyimler ve yaşantılarla gözden geçirilerek yeniden yapılandırılmasıdır (San, 2006). Söz konusu bu süreç, katılımcıların kendilerini ifade etmelerine ve yaratıcı doğaçlama uygulamaları yapmalarına fırsat tanıyan, öğrenci merkezli bir yaklaşım ve son derece etkili bir form olarak ifade etmelerine imkan verir (Winston, 2002). Drama ve doğaçlama çalışmaları, bireylere yaşadıkları dünyaya uyum sağlama ve karşılaşacakları sorunlarla 
mücadele etme firsatı tanıyan ve yaparak yaşarak öğrenme imkânı sağladığı için öğrencilerin hem duyuşsal hem de bilişsel olarak gelişimini olumlu etkilemektedir. Drama sürecinde bireyin düşüncelerinin, duygularının, bedeninin farkında olması, fikirler ve düşünceler geliştirmesi, etkileşim becerileri ve duyu organlarını kullanması çoğu zaman yaratıcı bir şekilde zihinsel resimlerini ve gerçeğin temsillerini yeniden şekillendirmektedir (Üstündağ, 2006; Toivanen, Komulainena ve Ruismäkia, 2011). Bunların yanısıra Pinciotti (1993) ve Yazar, Çelik ve Kök (2010) yaratıcı dramada öğrencilerin oyunlar, canlandırmalar ve rol oynama sırasında özellikle de değerlendirme aşamasında kendilerini daha rahat ifade ettiklerini, dünya hakkındaki bilinçlerinin ve çevreleri ile iletişimlerinin geliştiğini söylemekte ve yaratıcı dramanın bireyleri sanatsal açıdan daha duyarlı hale getirdiğini belirtmektedirler.

Yaratıcı drama etkinlikleriyle işlenen derslerde öğretmenin rolü ise hazır bilgi vermek yerine, öğrencilerin yeni bilgileri keşfetmelerine, yapılandırmalarına ve anlamlandırmalarına yardımcı olmak, bu tür bilgiler hakkında konuşmaları için ortam ve firsat yaratmaktır. (Andersen, 2000).

Yukarıdaki çerçeve doğrultusunda dramanın genel amaçları; yaratıcılığı ve hayal gücünü geliştirme, kendini tanıma, gerçekleştirme ve başkalarıyla iletişim becerisini geliştirme, demokratik tutum ve davranış geliştirme, estetik davranışlar geliştirme, eleştirel ve bağımsız düşünebilme becerisini geliştirme, işbirliği yapabilme, birlikte çalışma becerisi geliştirme, sosyal duyarlık yaratma, duygusunun sağlıklı bir biçimde boşalımı ve kontrolü, dil gelişimi, sözel ve sözel olmayan ifade becerisi eleştirel düşünme yeteneği, sosyal gelişim ve birlikte çalışma yeteneği kazandırma, bireylerin etik değerleri keşfetmelerine olanak sağlama, kendine güven duyma, teşvik ve karar verme, imge dünyasını geliştirme geliştirme olarak sıralanmaktadır (Adıgüzel, 2000; Adıgüzel, 2013)

Alanyazın incelendiğinde ise dramanın öncelikle kişilerin bireysel ve sosyal gelişimlerine iletişim, dil ve kendini ifade etme becerileri, yaratıcı düşünme, problem çözme, özgüven, işbirliği, kendini tanıma ve anlama, paylaşma, duyarlılık, empati, estetik hayal gücü gibi boyutlarda katkıları olduğu belirtilmektedir (Annarella, 1992; Metin, 1999; Okvuran, 2000; Akoğuz, 2002; Dikici, Koç ve Gündoğdu, 2003; Köksal Akyol, 2003; Yeğen, 2003, Turner, Mayall, Dickinson, Clark, Hood, Samuels, 2004; Demir, 2012; Taşar, 2012; Özşenler, 2013; Bütün, Tüzüner ve Duman, 2015). Sözü edilen bu katkılarının dışında alanyazındaki bazı çalışmalarda yaratıcı dramanın ayrıca, duyuşsal alanda tutumları etkilediği (Hurd, 1991; Yılmaz, 2015); çeşitli değerlerin kazandırılmasında da etkili olduğu (Aya, Günay ve Aydın, 2016) öğrencilerinin istikrarlı bütünlüğünün gelişimini sağladığ1 (Rusilowski, 2017) vurgulanmaktadır.

\section{Araştırmanın amacı}

Alanyazında yapılan araştırmalar incelendiğinde yaratıcı drama yöntemi, yaşantılara dayalı zengin bir öğrenme ortamı oluşturarak öğrencinin etkin bir şekilde öğrenme sürecine katılımını sağlayan, öğrenme mekânını sadece okul ve sınıfla sınırlamayan, etkili bir iletişim ve etkileşime imkan yaratarak öğrenci kazanımlarını ve başarısını üst düzeye çıkarabilecek bir yöntem olarak ön plana çıkmaktadır. Bu çalışmada Sosyal Bilgiler Öğretmenliği bölümündeki "İnsan İlişkileri ve İletişim” dersinde yaratıcı drama uygulamalarının "öğrenme, kişisel gelişim, mesleki gelişim, duygular, sosyal ilişkiler, değerler” boyutlarındaki etkilerine ilişkin öğrenci görüşlerinin belirlenmesi amaçlanmıştır. $\mathrm{Bu}$ amaca ulaşmak için İnsan "İlişkileri ve İletişim dersinin işlenişinde kullanılan yaratıcı drama etkinliklerine ilişkin öğretmen adayı öğrencilerin görüşleri nelerdir?” araştırma sorusu altında aşağıdaki sorulara yanıt aranmıştır: 
1. Yaratıcı drama etkinliklerinin iletişim dersine katkısına ilişkin öğretmen adaylarının görüşleri nelerdir?

2. Yaratıcı drama etkinliklerinin arkadaşlık ilişkilerine katkısına ilişkin öğretmen adaylarının görüşleri nelerdir?

3. Yaratıcı drama etkinliklerinin öğretmenlik becerilerine (ders işleme becerilerine) katkısına ilişkin öğretmen adaylarının görüşleri nelerdir?

4. Yaratıcı drama etkinliklerinin ders içi öğretmen-öğrenci etkileşimine katkısına ilişkin öğretmen adaylarının görüşleri nelerdir?

5. Yaratıcı drama etkinliklerinin diğer insanlarla ilişkilere olan katkısına ilişkin öğretmen adaylarının görüşleri nelerdir?

6. Yaratıcı drama etkinliklerinin duygulara katkısına ilişkin öğretmen adaylarının görüşleri nelerdir?

$\mathrm{Bu}$ altı soru 1şığındaki veri toplama sürecinde öğretmen adaylarının gerçekçi görüşleri yansıttıkları kabul edilerek araştırma bu varsayım üzerinde temellendirilmiştir.

\section{Yöntem}

\section{Araştırma Modeli}

$\mathrm{Bu}$ araştırmada deneysel modelin deneme öncesi desenlerden olan tek grup (kontrol grupsuz) öntest-sontest deneysel araştırma deseni kullanılmış ve araştırma verileri görüşme yoluyla elde edilmiştir. Neden-sonuç ilişkilerini gözlemek amacıyla araştırmacının kontrülünde uygulamaları gerçekleştirilen desenlerden biri olan tek grup öntest-sontest desende; bağımsız değişkenin uygulanmasından önce ve sonra ölçme işlemleri yapılır. Bu bu ölçmeler arasında ise denel işlem uygulanır (Karasar, 2003; Büyüköztürk, Kılıç Çakmak; Erkan Akgün, Karadeniz, Demirel, 2011). Söz konusu deneysel desenin ve veri toplama yönteminin uygulanması Şekil 1.de gösterilmiştir.

\begin{tabular}{|c|c|c|c|}
\hline Grup & Öntest & İşlem & Sontest \\
\hline \multirow[t]{3}{*}{ Tek grup } & Ön görüşme & İnsan ilişkileri ve İletişim dersinde yaratıcı & Son görüşme \\
\hline & (Yapılandırılmamış & drama etkinlikleri & (Yapılandırılmamış \\
\hline & Görüș alma formu) & & Görüş alma formu) \\
\hline
\end{tabular}

Şekil 1. Çalışmada Kullanılan Araştırma Modeli ve Veri Toplama Yöntemi

\section{Çalışma grubu}

Araştırma, 2016-2017 öğretim yılı bahar döneminde Mehmet Akif Ersoy Üniversitesi Eğitim Fakültesi Sosyal Bilgiler Öğretmenliği 3. sınıfında okutulan "insan ilişkileri ve iletişim” dersini alan 21 erkek, 33 kadın olmak üzere toplam 54 öğrenci ile gerçekleştirilmiştir. Uygun örnekleme (çalışma grubunun seçimi) koşulların ne olduğuna bağlıdır. Zamana, paraya, yere, konumun kullanılabilirliğine ya da cevaplayanlara dayalı örneklem seçebilir (Merriam, 2013). Bu çalışmadaki uygulamalar ders etkinliği çerçevesinde ve sınıftaki tüm öğrencilerin katılımını gerektirdiğinden dolayı kolay ulaşılabilir örneklem yöntemi tercih edilmiştir. 


\section{Veri Toplama Aracı}

Çalışmanın verileri yapılandırılmamış açık uçlu sorulardan oluşan bir görüşme formu ile toplanmıştır. Uygulama öncesi ve uygulama sonrasında kullanılan bu görüş alma formunda yaratıcı drama lideri, eğitim programları ve öğretim ve ölçme-değerlendirne alanlarında iki uzmanın görüşleri doğrultusunda geliştirilen ve araştırmanın amacı bölümünde belirtilen altı soruya yer verilmiştir. Çalışma öncesinde öğrencilere sınıf içi arkadaşlık ilişkileri, diğer insanlarla olan iletişimleri, ders hocalarıyla olan ilişkileri, derslerin öğretmenlik becerilerine katkılarına ilişkin görüşleri sorulmuştur. Çalışma sonunda da benzer sorularla oluşturulmuş form tekrar uygulanmıştır.

\section{Uygulama Süreci}

İnsan ilişkileri ve iletişim dersinin yaratıcı drama ile işlenebileceğinin uzmanlar yardımıyla kararlaştırılmasından sonra 12 hafta süren dersler için Tablo.1'de verilen konularda 2'şer ders saatlik atölye planları hazırlanmıştır.

Çalışmanın hemen başında tüm öğrencilerin sınıf içi ilişkiler ve iletişim hakkındaki düşünceleri yazılı olarak alınmıştır. Daha sonra dersin içeriği ve dönem boyunca yapılması planlanan uygulamalara ilişkin öğrenciler bilgilendirilmiştir. Bu çerçevede öğrencilerden beklenen tutum ve davranışlar açıklanmış, kendilerinin de beklentilerini dile getirmeleri sağlanmıştır. Bu tartışmalarda ortaya çıkan istek ve beklentiler doğrultusunda atölye planları tekrar gözden geçirilerek planlarda gerekli düzenlemeler yapılmıştır.

Çalışma kapsamındaki uygulamalar Mehmet Akif Ersoy Üniversitesi Sağl1k Kültür ve Spor Dairesine ait Avşar Han'daki çok amaçlı Salon-2 de gerçekleştirilmiştir. Çalışma süresince işlenen konuların akışı Tablo 1'de verilmiştir:

Tablo 1. Insan Illişkileri ve İletişim Ders Konuları ve Yaratıcı Drama Atölyeleri

\begin{tabular}{|l|l|l|}
\hline Ön görüşme & 5. İletişim ilkeleri & 9. İletişim çatışmaları ve çözüm yolları \\
\hline 1. Tanışma & 6. İetişimin niteliği & 10. İletişis çatışmaları ve çözüm yolları \\
\hline 2. Uyum-güven & Ara değerlendirme & 11. İletişimde dil \\
\hline 3. İletişim kavramı & 7. İletiş̧im engelleri & 12. Dinleme becerileri ve iletişim \\
\hline 4. İletişim ögeleri & 8. İletişim engelleri & Genel değerlendirme \\
\hline
\end{tabular}

Tablo 1'de görülen atölye konuları yaratıcı drama aşamaları (1sınma, canlandırma ve değerlendirme) doğrultusunda planlanarak 12 hafta boyunca 2'şer ders saati (toplam 90'ar dk.) olarak bizzat araştırmacı tarafından uygulanmıştır.

\section{Verilerin Analizi}

Yukarıda özellikleri açıklanan veri toplama aracıyla alt problemler doğrultusunda katılımcılardan yazılı olarak toplanan veriler 353 sayfalık bir veri seti oluşturmuştur. Her bir katılımcının yazılı görüş alma formuna verdikleri cevaplar madde madde incelenmiştir. Her maddeye ilişkin kodlar belirlenmiştir. Ortak olan kodlar bir araya getirilmiş ve 6 ana tema altında toplanmıştır. Her bir koda ilişkin görüşlerin frekans ve yüzdeleri alınarak bulgular tablolar üzerinden yorumlanmiştır. 


\section{Bulgular ve Yorum}

Verilerin analizi sonucunda uygulama öncesindeki grubun iletişim özellikleri ile uygulama sonrasında iletişimle ilgili öğrenmelerine ilişkin temalar Tablo 2' de verilmiştir:

Tablo 2. Öğrencilerin Uygulama Öncesi ve Uygulama Sonrasında İletişim Özellikleri ve İletişimle Ilgili Ögrenmeleri

\begin{tabular}{|c|c|c|c|c|c|}
\hline \multicolumn{3}{|c|}{ Uygulama Öncesi Temalar } & \multicolumn{3}{|l|}{ Uygulama Sonrası Temalar } \\
\hline I. İletişim Teması & f & $\%$ & İletişimi Öğrenme & f & $\%$ \\
\hline \multirow{3}{*}{$\begin{array}{l}\text { 1. Olumsuz öğrenci- Öğrenci } \\
\text { İletişimi } \\
\text { (Zayıf/kopuk iletişim) }\end{array}$} & \multirow{3}{*}{54} & \multirow{3}{*}{100} & 1. Olumlu iletişim kurma (konuşma) & 50 & 93 \\
\hline & & & $\begin{array}{l}\text { 2. Öğretmen-öğrenci iletişiminin nasıl olması } \\
\text { gerektiğini }\end{array}$ & 50 & 93 \\
\hline & & & 3. İletişim çatışmaları çözmeyi öğrenme & 45 & 83 \\
\hline $\begin{array}{l}\text { 2. Öğretim elamanı- öğrenci } \\
\text { etkileşimi (İletişim yokluğu) }\end{array}$ & 50 & 93 & $\begin{array}{l}\text { 4. İletişimde beden dili (jest mimik, göz } \\
\text { teması, ses tonu, yüzüne bakarak konuşma } \\
\text { vb.) }\end{array}$ & 44 & 81 \\
\hline 3. Öğrenciler arası gruplaşma & 52 & 96 & $\begin{array}{l}\text { 5. Problemleri (sorunları) fark etme ve } \\
\text { farkındalık kazanma }\end{array}$ & 43 & 80 \\
\hline 4. Dinlememe ve anlamama & 50 & 93 & 6. İletişim araçları (yolları) & 41 & 76 \\
\hline 5. Duyarsızlık- umursamazlık & 40 & 74 & 7. İletişim ve ilişkileri güçlendirme & 39 & 72 \\
\hline \multirow{2}{*}{ 6. Yalnızlık ve yalnızlık tercihi } & \multirow{2}{*}{30} & \multirow{2}{*}{56} & 8. İletişim engelleri & 38 & 70 \\
\hline & & & 9. Teknolojinin kötü kullanımı ve önlem alma & 5 & 9 \\
\hline
\end{tabular}

Tablo 2'de görüldüğü gibi uygulama öncesindeki grubun iletişim temasının özellikleri konusunda öğrencilerin tamamı öğrenci-öğrenci iletişiminin olmadığını ya da çok yetersiz olduğunu; \% 93'ü öğretim elemanı-öğrenci etkileşiminin olmadığını; \%96'sı sınıfta gruplaşmaların olduğunu belirtmişlerdir. Sınıf içi ve günlük yaşamdaki insan ilişkileri ile ilgili olarak katılımcıların \%93’ü dinlememek ve anlamamak üzerine kurulduğunu; \% 74'ü duyarsızlık davranışlarının olduğunu ve \% 56 'sı bireylerin yalnızlığı tercih ettiğini vurgulamıştır.

Uygulama sonrası iletişimle ilgili öğrenmeler temasında ise çalışma grubunun \% 93’ü iletişim kurmay1, öğretmen-öğrenci iletişiminin nasıl olması gerektiğini ve iletişim çatışmalarını çözmeyi öğrendiğini belirtmektedir. Ayrıca katılımcıların \% 81'i iletişimde beden dilinin (jest mimik, göz temas1, ses tonu, yüzüne bakarak konuşma vb.) ne kadar önemli olduğunu; \% 80’i iletişimle ilgili sorunları fark etme konusunda farkındalık kazandıklarından söz etmektedir. Yine bu tema ile ilgili olarak katılımcıların \% 76'sı iletişim araç ve yollarını, \% 72'si iletişim ve ilişkileri güçlendirmede neler yapılması gerektiğini, \% 70'i iletişim engellerinin neler olduğunu öğrendiğini ifade ederken \% 9'u ise teknolojinin kötü kullanımından ve bu duruma karşı önlemler alınması gerektiğinden bahsetmektedir.

Katılımcı görüşlerine göre uygulama öncesindeki grubun sahip oldukları iletişim özellikleri, hem iletişim sürecini oldukça olumsuz etkileyen etkenler olması hem de büyük oranda gözleniyor olması dikkat çekici bir durumken; uygulama sonrasında çalışma grubunun iletişimle ilgili kavram, özellik ve süreçlere ilişkin öğrenmelerin oldukça üst düzeyde gerçekleştiği sonucuna ulaşılmıştır. İletişim özellikleri ve iletişimle ilgili öğrenmeler konularında elde edilen öğrenci görüşlerinden örneklere yer verilmiştir: 
“...iletişim sorun ve çatışmalarının yaşanmaması için öğretmenlerin bu alanda kendini geliştirmesi gerektiğini anladım ...” (ö7,ö9,ö22)

“...iletişsim engelleri ve çatışmalarıyla karşılaştığımda nasıl bir yol izlemem gerektiğini ögretti...”(ö23, ö37)

“...iletişsimin dinleme ile başladığını öğrendim... ”(ö14, ö29, ö51)

“...insan ilişkilerinde sorun yaratan iletişim engellerinin neler olduğunu daha iyi anladım... ”, (ö5)

“...insanlarla konuşma tarzımıza, jest ve mimiklerimize dikkat etmem gerektiğini öğrendim... ” (ö11, ö19, ö21,ö29,ö 32, ö46, ö54)

“...dinlemiyoruz, empati yapmiyoruz vb. birçok iletişim sorunların yaratıyoruz. Ama hala kendimizin doğru olduğuna inanıyoruz, yanlışlarımızı görmek istemiyoruz. Ancak önyargılarımızdan kurtulduğumuzda insanların farklı olduğunu ve olduğu gibi kabullenmeyi ögrendiğimizde bu sorunların ortadan kalkacağına inaniyorum. Konuşamayarak çözülemeyecek bir sorun kesinlikle yoktur.” (ö10,ö15,ö30,ö36)

“...Ön yargllarımız insanların dış görünüşüne, klyafetine, cinsiyetine, ırkına dinine, siyasi görüşüne, kültürüne o kadar baklyor ve yorumluyoruz ki insanın özüne, karakterine bakmayl unutuyoruz. (ö4,ö13,ö17,ö34)”

“...bu dersin sonucunda fark ettim ki bütün insanlarla kurduğum ilişkilerde hep bir hata hep bir yanlış var, başarılı insan ilişkileri bence ilk olarak insanları ve onların doğasını doğru anlamaktan geçer, insanların belli koşullar altında neden ve nasıl tepki gösterdiklerini anladı̆̆ımız zaman ancak düzgün iletişim kurabiliriz." (ö7, ö29)

“...birbirimizi kirlp gergin bir ortam yaratmak yerine birbirimizi sevip bir birimizle konuşarak oluşan problemlerin ortadan kalkacağını öğrendim.” (ö9, ö14, ö26, ö37)

“...insanlar hakkında oluşturduğumuz önyargılardan, koyduğumuz katı kurallarımızdan var olan problemlerden vazgeçtiğimizde sağllklı bir iletişsim sağlandiğını gördüm bunu yolu ise birbirimizi dinlemekten geçer.” (ö9, ö12, ö46)

“...bu dersi almadan önce nelerin iletişim engeli olduğunu bilmiyordum. ” (ö14,ö23,ö28,ö3 3,ö34,ö38,ö42,ö47,ö51,ö52) 
Tablo 3. Uygulama Öncesi ve Uygulama Sonrası Öğretme-Öğrenme Ortamında Kazandıkları Mesleki Beceriler ile İlgili Görüşleri

\begin{tabular}{|c|c|c|c|c|c|}
\hline \multicolumn{3}{|l|}{ Uygulama Öncesi Temalar } & \multicolumn{3}{|l|}{ Uygulama Sonrası Temalar } \\
\hline Gözlenen mesleki beceriler & f & $\%$ & Öğretim sürecinin aşamaları & f & $\%$ \\
\hline 1. Anlatım yöntemi ve ezberleme & 42 & 77 & \multirow{3}{*}{$\begin{array}{l}\text { 1. Derse hazırlık } \\
\text { - Derse giriş ve ısınma } \\
\text { - İlgi ve dikkati artırma (hareketlilik) } \\
\text { - Öğrencileri güdüleme (Öğrenmeye } \\
\text { isteklendirme) }\end{array}$} & \multirow{3}{*}{52} & \multirow{3}{*}{96} \\
\hline $\begin{array}{l}\text { 2. Önceki eğitim yaşantıları ve } \\
\text { pasiflik }\end{array}$ & 42 & 77 & & & \\
\hline 3. Çekingen ve pasif öğrenci & 40 & 74 & & & \\
\hline 4. Resmi - formal bir ortam & 40 & 74 & \multicolumn{3}{|c|}{ 2. Öğretme-öğrenme etkinliklerinin niteliği } \\
\hline \multirow[t]{18}{*}{ 5. Tek düze eğitim } & 40 & 74 & - Yaparak-yaşayarak öğrenme & 52 & 96 \\
\hline & & & - Materyal kullanma & 51 & 94 \\
\hline & & & - Etkili iletişim & 50 & 93 \\
\hline & & & - Öğrenmeyi kolaylaştırma & 50 & 93 \\
\hline & & & -Öğrenmeyi oyunlarla destekleme & 50 & 93 \\
\hline & & & $\begin{array}{l}\text { - Öğretimde çeşitlilik yaratma (farklı } \\
\text { öğretme-öğrenme yolları kullanma }\end{array}$ & 48 & 89 \\
\hline & & & - Öğrenmedeöğrenci aktifliği & 48 & 89 \\
\hline & & & - Yöntem - teknik seçimi ve kullanımı & 46 & 85 \\
\hline & & & - Öğrenme firsat ve imkân yaratma & 42 & 77 \\
\hline & & & - Öğrenci seviyesine uygunluk & 41 & 76 \\
\hline & & & - Özgür ve kontrollü ortam & 39 & 72 \\
\hline & & & - Kitaba bağlı kalmama & 26 & 48 \\
\hline & & & $\begin{array}{l}\text { 3. Değerlendirme ve dönüt işlemleri } \\
\text { niteliği }\end{array}$ & 45 & 83 \\
\hline & & & 4. Olumlu öğretmen tutumları & 35 & 65 \\
\hline & & & 5. Öğretmenlik mesleğini sevme & 33 & 61 \\
\hline & & & 6. Yaratıcı ve özgün düşünme & 32 & 59 \\
\hline & & & $\begin{array}{l}\text { 7. Öğretimde mekan (sınıf dışı } \\
\text { mekanlar) }\end{array}$ & 25 & 46 \\
\hline & & & 8. Sınıf oturma planı (düzeni) & 23 & 42 \\
\hline
\end{tabular}

Tablo 3' te görüldügü gibi uygulama öncesi elde edilen verilerde öğretme-öğrenme ortam1 ilgili mesleki beceriler konusunda öğrencilerin \% 77'si süreçle ilgili yaşantılarında anlatım yöntemi, ezberleme ve öğrenci pasifliğinden; \% 74' ü ise resmi bir ortamın ve tek düze eğitim uygulamalarının varlığından söz etmişlerdir.

Çalışma sonunda ise bu süreçteki mesleki becerilerle ilgili olarak öğretmenlik mesleğine başladıktan sonra öğrencilerin \% 96'sı öğretim sürecinin giriş etkinliklerindeki (1sınma, dikkat çekme, güdüleme vb.) gibi yapılması gerekli olan uygulamaları yerine getireceklerini ifade etmişlerdir. Süreçte ise öğrencilerin \% 96's1 yaparak-yaşayarak öğrenmeye ve materyal kullanmaya ağırlık vereceklerini; \% 94'ü etkili iletişimi sağlamaya özen göstereceklerini belirtmişlerdir. Katılımcıların \% 93’ü öğrenmeyi kolaylaştırma ve oyunlarla destekleyeceklerini, farklı öğretme-öğrenme yolları kullanarak öğretimde çeşitlilik sağlayacaklarını; \% 89’u hem öğrenme sürecinde öğrencinin aktif 
olmasını sağlama konusunda hem de yöntem-teknik seçimi ve kullanımında daha dikkatli olacağını dile getirmiştir. Yine öğrencilerin \% 85'i öğrenmede firsat ve imkân yaratacağını, \%77'si öğrenci seviyesine uygun uygulamalar yapacağını; \% 76'sı özgür ve kontrollü ortam sağlayacağını; \% 26's1 kitaba bağlı kalmayacağını; \% 83'ü ise değerlendirme ve dönüt işlemlerini gerektiğinde yapacağını vurgulamıştır.

Yukarıdaki temaların yanı sıra öğretme- öğrenme sürecinde ele alınan farklı temalar da ortaya çıkmıştır. Bu çerçevede öğrencilerin \% 65’i olması gereken öğretmen tutumlarını sergileyeceklerini; \% 61'i öğretmenlik mesleğini seveceğini, \% 59'u yaratıcı ve özgün düşünme ortamı sağlayacağını \% 46'sı mekân sınırlaması olmadan her yerde ders işlenebileceğini ve \% 42'si ise sınıflarında belli bir orturma planı ve düzeni oluşturmayacaklarını ifade etmişlerdir.

Katılımcıların bu tema ile ilgili düşünceleri uygulama öncesinde -ders öğretim elemanlarıyla ilgili yaşantılarından dolayı- daha sınırlıyken ve büyük oranda geleneksel ve öğretmen merkezli eğitim uygulamalarını yansıtırken; uygulama sonrasında ise öğretmen olduktan sonra sergileyecekleri davranışlarla ilgili düşünceler açısından hem çeşitlilik göstermekte hem de oran bakımından zenginleşerek öğrenci merkezli eğitim uygulamalarına ilişkin olumlu bir bakış açısı yansıtmıştır. $\mathrm{Bu}$ tema ile ilgili öğrencilerin görüşlerinden bazı örnekler aşağıda verilmiştir:

“...drama ile birlikte derste daha hareketli ve daha dikkat çekici olmayı öğrendim. Kitaba bağlı kalmamayı ve çeşitlilik sağlamayl, çeşitli oyunlarla dersi daha verimli hale getirmeyi ögrendim." (ö2,ö14)

“...çok sayıda duyu organını kullanarak yaparak yaşayarak öğrenme imkânı veren ve çok çeşitli tekniklerle öğrenme imkânın sağlanması öğrencinin daha aktif, ezberden uzak eğlenceli hem de kalıcı şekilde öğrenmesini sağllyor.” (ö8, ö13,ö17,ö42,ö51)

“...dersin sadece kitaplardan ibaret olmadığını.” (ö4,ö32)

“...öğreticinin öğrenciye hem ahlaki hem de manevi açıdan örnek teşkil etmesi dışında drama ortamında kişisel becerilerini ve yeteneklerini sergileme imkânı bunulması ögrencilerin daha çok dikkatini çeker ve hayranlık uyandırır."(ö8, ö11,ö49)

“...bask altında işlenen bir dersten yeterince verim olmaz, o derse odaklanamaz, dersi anlamaz, hatta dersten ve ögretmeninden soğuyabilir.”(ö12,ö36,ö52)

“...dersin sonunda değerlendirme aşamasında herkesin birbirini görebileceği şekilde oturup bugün etkinliklerden ne anladı, ne işledik sorulartyla ders hakkında sorular sorarak dönütler alınması, ögrenmenin zamanında kontrol edilmesini sağlamaktadır. Dönütler slnavlarda alındiğında hem uzun bir zaman dilimi araya girmekte hem de ögrenmede sorunlar yaratmakladır." (ö6,ö18,ö53)

“...oynayarak- yaşayarak- eleştirerek-tartışarak öğrenmemizi sağladı, öğrenmeler bu şekilde daha kalıcl ve birbirinin üstüne yığılmamaktadır.” (ö6,ö12,ö24,ö35,ö48)

“...eğer öğretmenimiz düz anlatım yöntemini seçip dersini anlatsaydı aktiflik, bireyler arası etkileşimimiz ve duyarlılı seviyesi daha alt düzeyde olurdu, tanımları ve bilgileri ezberlerdik. "(ö6,ö12, 28,ö37,ö54)

“... bize yeni bir ufuk açtı. Sinıfa gelip defteri açıp iletişsim şudur, insan ilişkileri budur diye yazdırmak ve yazmaktan ibaret olmadlğın aslında o şekilde bir yöntemin bize hiçbir fayda sağlamadığını öğretti, bu yöntem bizi dersin içine aldı ve bizi gerçekten o dersin ögesi yapt.."(ö15,ö17,ö51) 
İnsan İlişkileri ve İletişim Dersinde Yaratıcı Drama Uygulamalarının Etkisine İlişkin Öğrenci Görüşleri

“...e ğitimini alıp da ögrrendiğim birçok öğretim yöntemi var; elbetteki her yöntemin de kullanıldiğl, etkili olduğu konular vardır. Hangi konunun hangi yöntemle işlenmesi gerektiği, hangi yöntemle işlenirse etkili olacă̆ öğretmenin bilecĕgi iştir, bende öğretmen olduğumda hangi konunun hangi yöntemle işlenmesi gerektiğimi dikkate alarak hareket edeceğim. Öğretmenlik hayatımda birçok yöntem kullanmam gerekecek.” (ö12,ö14,ö15,ö17, $\ddot{o} 25, \ddot{o} 29, \ddot{o} 44)$

“...öğrencimle aramda olan ilişkiyi belirli bir seviye de tutmayı kendime hedef edineceğim, çünkü başarılı ve her zaman daha da ögrrenme isteği olan ögrenci grubunun yaratılmasının ögretmen öğrenci ilişkilerinden geçtiğini düşünüyorum.” (ö12,Ö13,ö14, ö17, ö41)

“...öğretmen olduğumda işe ilk olarak sınıfta var olan oturma planını değiştirmekle işe başlarım, çünkü mevcut oturma planlarl ögrencilerin gruplaşarak birbirlerinden habersiz ve

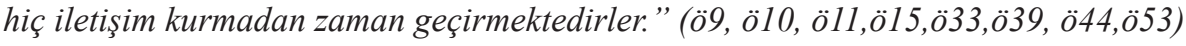

“...öğrencilerin fikirlerini özgürce söyleyebilecekleri bir ortam yaratmaya çalışırım.” (ö11, $14, \ddot{o} 26, \ddot{o} 35, \ddot{o} 40, \ddot{o} 47)$

“...oturma düzeni olarak $U$, çember ve etkinlik alanları olacak şekilde düzenleme yapmaya çalışırım.” (ö9,ö17,ö21,ö38,ö52,ö54)

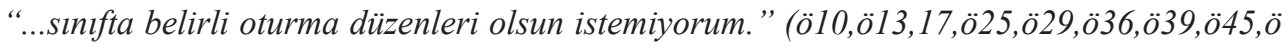
51)

“...ögrrencilerin yerlerini sürekli değiştirerek gruplaşmaları önler, arkadaşlık bă̆larını kuvvetlendirebilirim.” (ö2,ö6, ö9, ö12, ö33, ö43, o54)

“...ders dışında iletişimle ilgili oyunlar oynatıp onlara sağlıklı bir iletişimin nasıl olması gerektiğini anlatırım.” (ö7, ö14, ö31,ö37,ö43,ö52)

“...iletişimi güçlendiren sosyal aktiviteler yaparak öğrencilerimle arkadaş olabileceğimi, onlarlailetişimkurarakdersleridahaverimli işleyebileceğimi, dikkatlerinitoplayabileceğimi. ' (ö5, ̈9, $21, \ddot{o} 29, \ddot{o} 38, \ddot{o} 46)$

“...drama başta olmak üzere farklı yol ve yöntemleri kullanacağım. Sınıf ortamını düzenleme ve hakimiyet açısından oldukça faydall. Farklı materyal ve araç gereçlerden faydanırım. Bunları da ögrencilerin kapasitesine ve bilgilerine göre uygularım. Ses tonumu farklılaştırarak ve öğrencinin yüzene bakarak ders işlerim. ” (ö3,ö10,ö16,ö35,ö49)

“...gruplaşmaları önlemek adına her daim farklı kişilerle oturmalarını ve iletişim kurmalarını sağlarım” (ö8,ö43)”

“...bir öğrenci sınıftan ne kadar rahat olursa ve sınıfını ne kadar çok severse ders de o kadar istekli gelir.” (ö8)

“...materyallerle donatırım sınıfi ve onları korkmadan paylaşırım.” (ö6, $\ddot{o} 11, \ddot{o} 14, \ddot{o} 19, \ddot{o} 29, \ddot{o} 36, \ddot{o} 50)$ 
Tablo 4. Öğrencilerin Uygulama Öncesi ve Sonrasında Kişisel Özelliklerdeki Gelişim ile İlgili Görüşleri

\begin{tabular}{|c|c|c|c|c|c|}
\hline Uygulama Öncesi Temalar & $\mathbf{f}$ & $\%$ & Uygulama Sonrası Temalar & $\mathbf{f}$ & $\%$ \\
\hline 1. Kişisel özellikler & & & 1. Kişisel Özellikler & & \\
\hline - Empati yokluğu & 52 & 96 & - Özgüven duyma, & 52 & 96 \\
\hline \multirow[t]{18}{*}{ - Çekingen ve pasif olma } & 50 & 93 & - Sosyal girişimcilik / Girişkenlik & 48 & 89 \\
\hline & & & - Kendini ve yeteneklerini tanıma & 40 & 74 \\
\hline & & & - Cesaret & 38 & 70 \\
\hline & & & 2. Dil becerileri & & \\
\hline & & & - Kendini ifade etme & 44 & 81 \\
\hline & & & - Soru sorma & 43 & 80 \\
\hline & & & - Dinleme & 38 & 70 \\
\hline & & & 3. Düşünme becerileri & & \\
\hline & & & - Düşünme, fikir üretme & 40 & 74 \\
\hline & & & - Empati kurma becerisi & 36 & 67 \\
\hline & & & - Yaratıcı ve özgün düşünme & 35 & 65 \\
\hline & & & - Araştırma, bulma ve anlatma yeteneği & 32 & 59 \\
\hline & & & - Anlık cevap ve tepki (hazırcevaplılık) & 28 & 52 \\
\hline & & & 4. Davranış gelişimi açısından & & \\
\hline & & & - Doğal olma & 23 & 43 \\
\hline & & & - Sabır ve tahammül gösterme & 21 & 39 \\
\hline & & & - Kendini (duygularını, tepkilerini) kontrol etme & 18 & 33 \\
\hline & & & 5. Bedensel gelişim ve aktiflik & 13 & 24 \\
\hline
\end{tabular}

Tablo 4’te görüldüğü gibi kişilik özellikleri olarak uygulama öncesinde öğrencilerin \% 96’s1 empati yokluğundan, \% 93'ü ise çekingenlik özelliğinden dolayı pasif kalmaktan söz etmişlerdir. Öte yandan yine aynı tabloda uygulama sonrası kişilik gelişimi özellikleri ilgili olarak öğrencilerin \% 96's1 özgüven kazandıklarını; \% 89'u çekinkenlikten kurtularak sosyal girişimciliklerinin arttığını, \% 74'ü kendini ve sahip olduğu yetenekleri tanıdığını ve \% 70'i ise cesaret kazandıklarını belirtmektedir. Bunların dışında düşünme becerileriyle ilgili olarak katılımcıların \%74'ü düşünme, fikir üretme; \% 67'si empati kurma; \% 65'i yaratıcı ve özgün düşünme becerilerinin; \% 59'u araştırma, bulma ve anlatma yeteneğinin; \%19'u ise anlık cevap ve tepki (hazırcevaplılık) özelliğinin geliştiğini ifade etmektedir. Ayrıca davranışları açısından katılımcıların \% 43'ü doğallık, \% 39’u sabır ve tahammül gösterme; \% 33’ü kendini (duygularını, tepkilerini) kontrol etme açılarından kendilerini geliştirdiklerini belirtirmektedir. Çalışmaların kendilerine bedensel gelişim ve aktiflik sağladı̆̆ını söyleyenlerin oranı ise $\% 24$ olarak belirlenmiştir

Katılımcıların kişisel özellikler temasında uygulama öncesindeki görüşleri iki özellikle sınırlı kalırken uygulama sonrasında bu tema ile ilgili belirtilen düşünce ve özellikler oldukça zenginleşmiş, hem kapsam hem de oran olarak büyük bir değişimi yansıtır hale gelmiştir. Öğrencilerin bu tema ile ileri sürdükleri görüşlerden bazıları örnek olarak aşağıda verilmiştir:

“...dikkat, konuşma, düsünme, üretme, kendini ifade etme gibi becerileri kazandırırdl." (ö3,ö8,Ö11, Ö18,ö26, ö34,ö40,ö42,ö53) 
İnsan İlişkileri ve İletişim Dersinde Yaratıcı Drama Uygulamalarının Etkisine İlişkin Öğrenci Görüşleri

“...empati becersi, karşımızdakini dinlemeyi kazandırdı (ö10, ö12, 17, ö19, ö23, ö28, ö35, $\ddot{o} 43, \ddot{o} 48, \ddot{o} 51)$

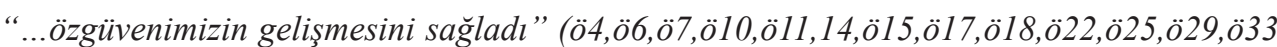
, $39, \ddot{0} 45)$

“...oldukça etkili bir ders işleme yöntemidir. Bu ders birbirimize daha hoşgörülü olmaya, kaynaştırmaya, konuşturmaya karşı bizi geliştirdi. Sınıfta yüz yüze bakmadı̆̆ım konuşmadığımı insanlarla bir araya gelme firsatı yarattı. Bu derste özellikle özgüven olarak kişiliğimi ön plana çıkarabilecĕ̆im, çekinmemem gerektiğini ögrrendim.” (ö1)

“...ilerleyen derslerde utangaçlık, çekingenlik, korku yerini mutluluğa, eğlenceye, neye atılganlı̆̆a, özgüvene bırakt, kendimden emin davrandım. ”(ö12,ö39)

“...yaratıcı düşünceler geliştirmemizi, kendimizi ifade etme ve yeteneklerimizi geliştirme imkânı sağladı.” (ö1, ö5,ö35)

“...ders birbirimize karşı konuşmamızı, üslubumuzu, bakışımızı, gülü̈sümüzü bile değiştirdi, birbirimizle samimiyetimiz arttı.” (ö15,ö32)

“...doğaçlamalar bize meslek hayatımızda hazırcevaplılı̆̆ geliştirebilir.” (ö16)

“...doğaçlamalarda yeteneklerimizin farkına vardık. Illetişime istekli hale geliyoruz. ”(ö2,ö15

“...insanlara karşı daha sabırlı ve anlayışlı alınması gerektiğini kazandım.” (ö2,ö27,ö48)

“...yapmaktan utandı̆̆ımız ya da çekindiğimiz şeyleri daha rahat yapmaya başladık.”

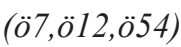

“...herkes bize bakarken çok rahat şekilde etkinliğimi gerçekleştirdim.” (ö1)

“...her şeyden önce konuşmanın yanı sıra karşımızdaki kişiye empati kurarak onun ne duruma düşeceğini ölçerek tartarak duygu ve düşüncelerimizi belirtmeye başladık. ”(ö7,ö21,ö53)

“...kendimi keşfetme şansı buldum, daha önce hiç bu tarz etkinliklerde bulunmamış hep uzak durmuştum toplumda aykırı hareket etmekten farklı hareketlerde bulunmaktan kaçınmıştım, artık doğal, içimden geldiği gibi davranabiliyorum.” (ö3)

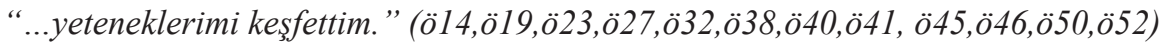

“...duygularımı kontrol etmeyi ögrendim, öfke ve sevinçlerimi heyecanımı nasıl kontrol

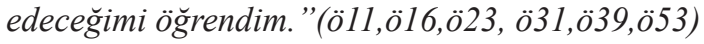

“...empatiyi kurarak insanların hangi durumlarda sevindiklerini ya da korktuklarinı anlamaya çalışıyorum. ”(ö11,ö48)

“...daha öncesinde sınıfımda veya günlük yaşamımda arkadaşlarımın, insanların yüzlerine bakmıyordum, oysaki iletişimde tüm bedenin mesaj verdiğini öğrendim. ”(ö14) 
Tablo 5. Öğrencilerin Uygulama Öncesi ve Sonrasında Değerler ile İlgili Görüşleri

\begin{tabular}{|c|c|c|c|c|c|}
\hline Uygulama Öncesi Temalar & f & $\%$ & Uygulama Sonrası Temalar & f & $\%$ \\
\hline 1. Değerler & & & 1. Değerler & & \\
\hline \multirow{2}{*}{ - Önyargıların olumsuz etkisi } & \multirow{2}{*}{52} & \multirow{2}{*}{96} & - Önyargısızlık (önyargılı olmama) & 54 & 100 \\
\hline & & & - İnsanları anlama çabası & 52 & 96 \\
\hline - Şekilcilik dış görünüş & 44 & 81 & - Demokratik davranma & 50 & 93 \\
\hline \multirow[t]{5}{*}{ - Cinsiyet ayrımcılığ 1} & 36 & 67 & - Hoşgörülü ve anlayışlı olma & 50 & 93 \\
\hline & & & $\begin{array}{l}\text { - Farklılıklara saygi duyma (Bireysel ve } \\
\text { kültürel farkl11ıklar) }\end{array}$ & 50 & 93 \\
\hline & & & - Gönüllü olma & 48 & 89 \\
\hline & & & - Paylaşma & 48 & 89 \\
\hline & & & - Sayg1 duyma & 47 & 87 \\
\hline
\end{tabular}

Tablo 5 incelendiğinde sahip olunan değerler temasında uygulama öncesi öğrencilerin \% 96'sı insan ilişkilerinde önyargılarının olumsuz etkisinden; \%81'i de şekilcilik ve dış görünüşe önem verdiklerinden ve \% 67'si ise cinsiyet ayrımcılığının etkisinde davrandıklarından söz etmişlerdir. Yine aynı tabloda görüldüğü gibi uygulama sonrasında katılımcıların tamamı insan ilişkileri ve iletişim sürecinde önyargılı olmamak gerektiğini; \% 96'sı insanları anlamak için çaba gösterilmesi gerektiğini, \% 93'ü ise demokratik davranılması, hoşgörü ve anlayış gösterilmesini, bireysel ve kültürel farklılıklara saygı duyma değerlerini kazandıklarını dile getirmişlerdir. Ayrıca katılımcıların \% 89'u gönüllülük ve paylaşma; \% 87'si ise saygı duyma davranış ve değerlerini kazandıklarını belirtmektedirler.

Öğrencilerin uygulama öncesinde değerler teması ile ilgili olarak sadece üç temel ve aynı zamanda olumsuz özelliklere büyük oranlarda sahip oldukları gözlenirken; uygulama sonrasında ise hem önceden sahip oldukları olumsuz değer anlayışlarının değiştiği hem de yeni kazandıkları değer özelliklerinin nicelik ve nitelik olarak olumlu yönde artış gösterdiği gözlenmiştir. Bu değerlerle ilgili öğrenci görüşlerinden bazı örnekler aşağıda verilmiştir:

“...biz o kadar çok birbirimizin memleketi, ırkl, cinsi, klyafet gibi özellikleriyle ilgilenmişiz ki konuşabileceğimiz ortak bir şeyler çok da güzel yapabileceğimiz birlikte eğlenebileceğimizi birlikte var olduğumuz unutmuşuz. Hatta en kötüsü nerdeyse üç yllın sonunda sinıftaki bazı arkadaşların isimlerini bile bilmediğimi fark ettim. O insanlarla iletişime geçtiğimde ortak bir payda içinde olduğumda eğlenebileceğimi konuşabileceğimi fark ettim. ”(ö4,ö11,ö48)

“...drama ile tabularımı yıktım, belli başlı kişilerle değil, herkesle konuşabileceğimi ögrendim.” (ö11,ö14,ö27,ö43)

“...herkesin kendine özgü hal ve hareketlerinin olabileceğini ve bunu kimsenin yadırgamam gerektiğini anlatırım.” (ö7)

“...hâlbuki her insan bir değer, her farklı insan bir deneyim, bir tecrübe ve ödül. Kendimizi başka insanlara kapattığımı sürece, ön yargılardan kurtulamadlğımız sürece...” (ö4, ö32,ö54)

“...kendimize karşı özgüvenimiz, arkadaşlarımıza karşı da güven duygumuzu artırmıştır. Grup etkinliklerinde fikirlerimizi ileri sürerken farkl özelliklere sahip olduğumuzu keşfettik bu farklılıklar dâhilinde paylaşmanın ve başarıya ulaşmanın tadını tattık. "(ö6,ö16,ö24,ö38,ö51) 
İnsan İlişkileri ve İletişim Dersinde Yaratıcı Drama Uygulamalarının Etkisine İlişkin Öğrenci Görüşleri

“...Duygularımın değiştiğini, hoşlanmadı̆̆ım insanlara karş̧ biraz daha ılımlı olmayl, bana uzak gelen ya da kafa yapılarımızın uyuşmayacağını düşündüğüm insanlara karşı." (ö4,ö33,ö49)

“... öncelikle insanlara önyargıyla yaklaşmamayl, onlar hakkında bilip bilmeden konuşmamayı dlş görünüşüne göre insanlarl yargılamamayı her kim olursa olsun insanlara karşı kibar, nazik ve iyi bir iletişim içinde olmalyyız." (ö11, ö15,ö22,ö27,ö39)

“...bazı şeyleri anlamamız için bazen kendimizi onun yerine koyup öyle davranmamız gerekir.” (ö7)

“...hepimizin farklı düşünceleri olabilir, bu iletişim kurmamıza bir engel değildir, insanları tanımadan, konuşmadan yaşamadan bilemeyiz, o yüzden ön yargılarımızı yıkıp insanlara öyle yaklaşmallyız."(ö4,ö9,ö17,ö52)

“...Insanlar her ne kadar faklı olsa da birbirlerinden her daim bir şeyler öğrenmeye açı olduklarında en azından bir yöreye ait kelime, yemek, şarkl, türkü hatta şive ögrenilirler, kültürel alışveriş sağlanır, ön yargılar bir kenara bırakılmalı." (ö8)

“...Insanlara kendilerini tanıtmalarına izin vermem gerektiğini anladım.” (ö14,ö33)

Tablo 6. Öğrencilerin Uygulama Sonrası Sosyal Özellikleri ile Illgili Görüşleri

\begin{tabular}{|c|c|c|c|}
\hline \multirow{16}{*}{ 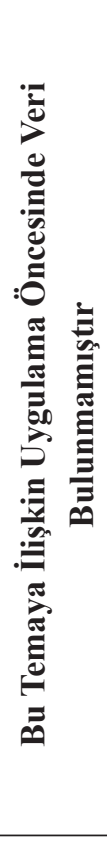 } & Uygulama Sonrası Temalar & $\mathbf{f}$ & $\%$ \\
\hline & 1. Sosyal gelişim & & \\
\hline & - Farklı insanlar /duygular vb. tanıma & 52 & 96 \\
\hline & 2.Etkileşimi artırma & & \\
\hline & - Samimiyet & 52 & 96 \\
\hline & - Kaynaşma (yakınlaşma) & 50 & 93 \\
\hline & - Gruplaşmaların azalması & 50 & 93 \\
\hline & - Yardımlaşma ve dayanışma & 50 & 93 \\
\hline & - Görüşs paylaşımı (fikir alışverişi) & 48 & 89 \\
\hline & - İşbirliği & 48 & 89 \\
\hline & - Paylaşım & 47 & 87 \\
\hline & - Kişilere güven duyma & 46 & 85 \\
\hline & - Sosyalleşme & 46 & 85 \\
\hline & - Görev dağılımı ve paylaşımı & 43 & 80 \\
\hline & - Birlikte karar alma & 43 & 80 \\
\hline & 3. Rol kişisiyle özdeşim kurma (canlandırdığı farklı kişiliklerin yaşadığı duygular) & 34 & 63 \\
\hline
\end{tabular}

Tablo 6'da görüldüğü gibi uygulama öncesindeki katılımcılar sosyal özellikleri konusunda herhangi bir görüş belirtmemişlerdir. Uygulama sonrasında ise öğrencilerin \% 96'sı farklı insanlar (duygular, özellikler vb.) tanıdıklarını ve farklılıkları gördüklerini belirtmektedirler. $\mathrm{Bu}$ temanın etkileşim alt boyutunda ise öğrencilerin \% 96'sı samimiyet kazandıklarını; \% 93'ü kaynaşma, yakınlaşma, yardımlaşma ve dayanışma göstediklerini, sınıftaki gruplaşmaların azaldığını; \%89'u işbirliği ve fikir alışverişi yaptıklarını belirtmişlerdir. Ayrıca bu alt boyutla ilgili olarak katılımcıların \% 87'si kişilere güven duyma davranışı gösterdiklerini; \% 85'i paylaşım ve sosyalleşme yaşadıklarını; \% 80'i ise görev dağılımı ve paylaşımı ile birlikte karar alma süreçlerinde olumlu davranışlar kazandıklarını söylemişlerdir. Bu görüşlerin yanı sıra katılımcıların \% 63 'ü rol kişisiyle özdeşim kurarak canlandırdığı farklı kişiliklerin yaşadığı duyguları yaşadığını dile getirmiştir. 
Uygulama öncesinde katılımcılar sosyal özellikleri konusunda herhangi bir görüş belirtmezlerken, uygulama sonunda öğrenci görüşlerine göre katılımcı grubun oldukça olumlu ve yüksek oranlarda sosyal gelişim özellikleri kazandıkları ortaya çıkmaktadır. Sosyal gelişim konusuda öğrenci görüşlerinden bazıları aşağıda sunulmuştur:

“...sınıf ortamımızla ilgili nefretimizin ortadan kalkmasını sağladı.” (ö9)

“...sınıf olarak bizi yakınlaştırdı, konuşmadığımız, kırgın olduğumuz ya da sevmediğimiz arkadaşlarımızla iletişime girmek durumunda kaldık, önceleri zorunlu gibi görmemeye

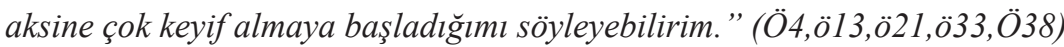

“...bu dersle sinıftakilerle daha fazla haşir neşir olduk herkesi ayrı ayrı dinleyip hep beraber hareket etmeye başladık.” (ö7)

“...farklılıkların, önyarglların, cinsiyetlerin bir kenara bırakılamaması bazen de etnik kökenlerin ve buna bağll olarak siyasi düşüncelerin de etkisiyle bireyler arasında oluşan ve birinci sınıftan itibaren hocalarımızın çabasıyla da her ne kadar aşılmaya çalışılsa da sınıfimız içinde zamanla oluşan ve bir türlü önüne geçilemeyen ikişerli bazen de daha fazla oluşan gruplaşmanın bu dersteki uygulamalar sayesinde 3 sene boyunca birbiriyle selamlaşmanın ilerisine geçmeyen sınıf arkadaşlı̆̆ olarak nitelendirilen ilişkilerimin bir nebze de olsa önüne geçişmiş oldu. ”(ö8,ö12,ö16,ö47)

“...etkinliklerde farklı gruplar belirlendiği için daha önce aynı ortamda bulunmama rağmen hiç konuşmadı̆̆ım arkadaşlarla konuşma-paylaşma-dayanışma ve onlara saygı duyma kavramlarının gelişmesini sağladı.” (ö6,ö12,ö17,ö42)

“...sınıfımız kız-erkek diye ayrılmış durumdayız. Kızlar erkeklerle pek konuşmaz, erkeklerde kızlarla. Hatta sınıfta kızlar ön sıralarda, erkekler arka sıralarda oturur... ama bu ders durumu biraz olsa da yıkmayı başardı bence... bu durum sınıf dışında da etkisini gösterdi, sadece dersle sınırlı kalmadı... keşke böyle bir dersi birinci ya da ikinci sınıfta görmeye başlasaymışız... Belki bir daha geri getiremeyeceğimiz bu güzel yıllarımızı daha güzel birlikte geçirebilirdik." (ö4)

“...bu dersten önce okul hayatımda arkadaşlık ilişkilerimi yok denecek azdl, birinci sınıftan üçüncü sınıfa kadar böyle devam etti. Ama bu drama dersiyle birlikte arkadaşlık ilişkilerimi her geçen hafta gelişti. Önceden sınıf içinde bırakın konuşmayı birbirimize selam dahi vermiyorduk... bu drama dersiyle birlikte ilişkilerimiz her geçen gün arttı sınıf içinde yada dışında birbirimizi gördügümüzde selam veriyor ve hal hatır soruyorduk.” (ö3,ö15,51)

“...kendimize karşı özgüvenimiz, arkadaşlarımıza karşı da güven duygumuzu artırmıştır. Grup etkinliklerinde fikirlerimizi ileri sürerken farkl özelliklere sahip olduğumuzu keşfettik. Bu farklılıklar dâhilinde paylaşmanın ve başarıya ulaşmanın tadını tattık."

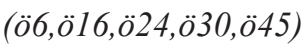

“...bu ders bu teknikle işlenmeseydi mezun olup gittiğimizde ayn ortamda 4 yılı beraber geçirdiğimiz arkadaşlarımızla belki de hiç konuşmamış belki de kırgın olduğum arkadaşlarımla kırgın olarak ayrılmış olacaktım, ama bu ders sayesinde sınıftaki tüm arkadaşlarımla konuşma firsatı buldum. "(ö9)

“...şu an sınıftaki tüm arkadaşlarımla ilgili az çok bir düşüncem var kim neleri sever, ne yapmaktan hoşlanır nasıl bir kişiliğe sahip ...vb.” (ö19)

“...sonuç olarak 3 yıl boyunca hiç diyaloğa geçmemek bize bir şeyler kazandırmamış. Aksine çok şey kaybetmişiz kendimizden... (ö3,14, ö33) 
İnsan İlişkileri ve İletişim Dersinde Yaratıcı Drama Uygulamalarının Etkisine İlişkin Öğrenci Görüşleri

“...üçüncü sınıfta olmamıza rağmen hiç konuşmadı̆̆ımız arkadaşlarımızla konuştuk. ”(ö16)

“...akadaşlarımla ilgili ön yargılarımı bir kenara bırakıp tüm arkadaşlarımla konuşup sohbet ederek grup oyunları oynamama katkı sağladı.” (̈̈9)

“...zayıf olan arkadaşlık ilişkilerimin güçlenmesine ve sınıfta hiçbir iletişim kurmadiğım arkadaşlarımla ders süresi ilerledikçe iletişim kurma imkânı.” (ö9,12,ö15,ö48)

“...arkadaşlarımla ilgili önyargılarımın zaman geçtikçe ortadan kalkmasına yardımcı oldu bunun sonucunda arkadaşlarımla aynı grup içinde yer alıp grup ruhunun geliştiğini fark ettim birlikte hareket ederek birbirimizi dinlemeyi takip etmeyi ve birbirimizle konuşup iletişim kurmayı başardık. ”(ö9,ö11,ö41)

“...Bu dersten önce birbirimize ne kadar soğuk davrandığımızı, bir birimizle mesafeli olduğumuzu aynı sınıfta olmamıza rağmen birbirimizden çok uzak olduğumuzu ve bu dersten sonra her geçen gün ilişkilerimizin güçlendiğini ve yakınlaştığımızı fark ettim."

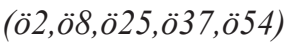

“...Önce sınıfımızda fazlasıyla gruplaşma söz konusuydu. İsmini dahi bilmediğim ya da fark etmediğim, görmediğim kişiler vardl. Hiçbir şekilde kendi arkadaş grubumuz dişında kimseyle diyaloğa geçmezdik. Diyaloğa geçmek bir yana yüzümüze bakmazdık. Bu şekilde olduğu takdirde de bir özgüvensizlik çekinme ve önyargılar meydana geliyordu. Birçok arkadaşımızla hiç konuşmamış olsak bile onun hakkında fikir sahibi olduğumuzu düşünüyorduk. " (ö10,ö13, $\ddot{o} 23, \ddot{o} 39, \ddot{o} 51)$

“...arkadaşlık ilişkilerimizde büyük katkı sağladı ve birbirimizi tanıma, sohbet etme imkanı

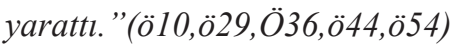

“...canlandırdı̆̆ım karakterdeki kişilerin yaşadığ o anki duyguları (sevinç, üzüntü, sinirlenme, endişelenme) yaşadım bu duygu durumlarında sakinliğimi ve durgunluğumu koruyamadı̆̆ımı gördüm.” (ö2,ö15,53)

“...ilk kez yüz yüze bakıyorduk sınıfımızdaki kutuplaşmalar dağıldı, birbirimize karşı ördüğ̈̈müz duvarlar aralandl. ”(ö14)

“...grup oyunlarımızda bir liderin düşüncelerine bağlı kalmadık, kendi düşüncelerimizi ortaya koyduk, kabul görmese bile grubun fikrine uymayı, ortak karar almayı ögrendik." (ö14,ö27)

“...sadece not dışında, ders dışında bir diyaloğumuzun olabileceğini ve bunu aslında mümkün olabileceğini düşünüyorum not dışında başka bir dili konuşabileceğimiz bir ortamın olduğunu gördüm (ö4)

“...arkadaşlık ilişkilerimiz olumlu yönde etkilenmiştir. Çünkü drama sayesinde sınıf ortamından uzaklaşıp daha samimi bir ortama girme firsatı bulduk ve bu ortamda birbirimizle hep diyalog halinde olduk, sınıfta bir sıra arkamızdan haberimiz olmazken bu yöntemde hep iç içe olduk." (ö15) 
Tablo 7. Öğrencilerin Uygulama Öncesinde ve Uygulama Sonrasındaki Duygu Özelliklerinin Karşılaşıtırılması

\begin{tabular}{lcclcc}
\hline Uygulama Öncesi Temalar & f & $\mathbf{\%}$ & Uygulama Sonrası Temalar & f & \% \\
\hline Duygular & & & Duygular teması & & \\
Derslerin sıkıcılığı & 40 & 74 & Eğlenme & 52 & 96 \\
Soğukluk (sınıf ortamı) & 32 & 60 & Derse katılımda isteklilik & 50 & 93 \\
Nefret (sınıf ortamı) & 28 & 52 & Komik, güldürücü & 48 & 89 \\
& & & Mutlu olma (mutluluk) & 47 & 87 \\
& & & Rahat hissetme & 43 & 80 \\
& & & Rahatlama (psikolojik ve bedensel) & 38 & 70 \\
& & & Fiziksel temas & 15 & 27 \\
\hline
\end{tabular}

Tablo 7'de görüldüğü gibi katılmc1 grubun \% 74'ü derslerin sıkıc1lı̆̆ından; \% 60’1 sınıf ortamındaki ilişkilerin soğukluğundan; \% 52'si ise kendi sınıfına karşı hissettiği nefret duygusundan söz etmiştir. Uygulama sonrasında ise öğrencilerin \% 96's1 eğlendiklerini, \% 93'ü bu dersin etkinliklerine katılmada istekli olduklarını, \% 89'u uygulamaları güldürücü bulduklarını, \% 87'si mutluluk duydukların belirtirken, \% 80'i kendilerini rahat hissettiklerini ve psikolojik ve bedensel rahatlama yaşadıklarını, \% 27'si arkadaşlarıyla fiziksel temasta bulunabilmenin yarattığı duyguyu hissettiklerini dile getirmişlerdir.

Diğer temalarda olduğu gibi duygular temasında da uygulamadan önce grubun büyük çoğunluğu olumsuz üç duygudan söz ederken; uygulama sonrasında büyük oranda olumlu ve çeşitli duygular yaşadıkları gözlenmiştir. Duygular temasıyla ilgili olarak öğrenci görüşlerinden bazıları şunlardır:

“...ve gerçekten gülebildiğimi mutlu olduğumu, bir şeyler yapabildiğimi gördüm.” (ö12)

“... güldürücü bir ortam yaratıp rahatlamamızl sağllyor.” (ö3, ö8, ö14,ö19,ö21,ö34,ö44,ö53)

“...kurallar ve sinıf yok, ögrencinin rahat olması ön planda, koş zipla, gül eğlen ... yapılan etkinliklerde her şey bana ve benim özgür iradem bağll olduğu için istediğimi söyleyip istediğim davranışl sergiliyorum, yani doğal oluyorum. "(ö8,22,ö33,ö49)

“...dersteilkzamanlarçekinipsikılırken,şimdikoşakoşagidiyorum.”(ö8,ö12,ö17,ö35,ö46,ö54)

“...çekindin utandım, drama yapamam diye korktum.” (ö12,ö27,ö33,ö48)

“...bu derste normalde yapamayacağımız şeyler, hareketler yapmak durumunda kaldık... ilk derslerde bunun yabancıliğını ve zorluğunu çektim, fakat ögretmenin yarattı̆̆ atmosfer ögretmenin ögrrencilerle diyaloğunun ne kadar önemli bir faktör olduğunu gösterdi. Çünkü karşımda yaptı̆̆ım hareketlere kızan beni kısttlayan ya da beni notla tehdit eden bir hoca ya da durum yoktu, bu durum beni ve ya da öğrencileri biraz daha rahatlatan bir durumdur."(ö4)

“...ögretmenimiz bize komut vermek yerine bizimle birlikte oyunlara katılmış, bize öğretmeye çalıştıklarına kendini de dâhil etmiştir. Bu şekilde bizimle birlikte etkinliklere katılması yol göstermesi içtenlikle olaylara katılması bizi motive etmiştir."(ö15)

“...derse ilk girdiğimiz gün çok fazla çekingen tavırlar sergiliyorduk, herkes kendi arkadaş gruplarıyla bir arada olmak, aynı gruba düşmek için uğraş veriyordu sınıftaki gruplama ilk 
İnsan İlişkileri ve İletişim Dersinde Yaratıcı Drama Uygulamalarının Etkisine İlişkin Öğrenci Görüşleri

gün fazlasıyla hissedilmişti. Daha tanışma ekinlikleriyle 3 yıldır aynı sınıfta olmama rağmen tek bir kelime konuşmadığımı hatta yüzünü bilmediğim kişiler olduğunu fark ettim.” (ö14)

“...fiziksel temasta bulunduk.”(ö6,ö18,ö39,ö46,ö51)

...bu derste en çok hoşuma giden durum bütün ağırlıklarımızı, yüklerimizi yani ayakkabı, çanta, telefon gibi yüklerimizi birakmak beni çok rahatlattı." (ö4)

\section{Sonuç ve Öneriler}

İnsan ilişkileri ve iletişim dersinde yaratıcı drama uygulamalarının etkisine ilişkin öğrenci görüşlerinin araştırıldığı bu çalışmanın uygulama öncesi ve sonrasında elde edilen verilerinin analizi sonucunda "öğrenme, mesleki gelişim, değerler, kişisel gelişim, sosyal ilişkiler ve duygular" olmak üzere altı tema ortaya çıkmıştır.

Çalışma sonunda "öğrenme temasında" öğrencilerin iletişim konusunda farkındalık kazandıkları, iletişim araç ve yollarını, iletişim ve ilişkileri güçlendirmede neler yapılması gerektiğini, iletişim çatışmalarını nasıl çözecekleri, iletişim engellerini nasıl ortadan kaldıracakları, iletişimde beden dilinin önemi ve teknolojinin kötü kullanımı gibi ders konularını daha etkili ve kolay öğrendikleri belirlenmiştir. Elde edilen bu sonuçlar yaratcı drama uygulamalarının başkalarını dinlemeyi (Öztürk, 2001), yazılı ve sözlü iletişim ve dil becerilerini (Gönen ve Dalkılıç, 2000; Hendy ve Toon, 2001; Akoğuz 2002; Er, 2003; Rances, 2005; Fenli, Acar ve Sahin, 2009; Gökçearslan Çiftçi ve Altınova, 2017), göz teması kurmayı (Öztürk, 2001), beden dili kullanımını (Almaz, İşeri ve Ünal, 2014) olumlu yönde etkilediğinin belirlendiği araştırma sonuçlarıyla da örtüşmektedir. Ancak iletişim araç ve yolları, iletişim ve ilişkileri güçlendirmede neler yapılması gerektiği, iletişim çatışmalarının nasıl çözüleceği, iletişim engellerinin nasıl ortadan kaldırılacağı, iletişim süreçlerinde teknolojinin kötü kullanımı gibi iletişim dersinin kendine özgü içeriği ile ilgili kazanımlara ilişkin alanyazında incelenmiş çalışmalarda olumlu ya da olumsuz ilişkiden bahsedilebilecek sonuçlara ulaşılamamıştır.

Mesleki gelişim temasında ise yapılan etkinliklerin öğrencilere öğretmenlik mesleğini sevdirdiği, öğretmen adaylarına mesleki yaşamlarında nasıl öğretecekleri, öğretirken hangi yöntem- teknikleri nasıl kullanacakları, öğretim sürecininin aşamalarını dikkate alarak süreci nasıl düzenleyecekleri, öğretimde çeşitlilik sağlama ve materyal kullanımı, öğrenci ile bu süreçte nasıl etkili iletişim kuracakları gibi konularda katkı sağladığı belirlenmiştir. Bu tema ile ilgili olarak yaratıcı dramanın yaparak-yaşayarak öğrenmeyi sağlama (Aytaş, 2013) özelliği dışında alanyazında ilgili araştırmalara rastlanmamıştır.

$\mathrm{Bu}$ çalışmalar aracılığıyla kişisel gelişimle ilgili olarak; öğrencilerin özgüven ve cesaret kazandıkları; çekinkenlikten kurtularak sosyal girişimciliklerinin arttığı, kendini tanıma ve ifade etme, düşünme, fikir üretme, empati kurma, yaratıcı ve özgün düşünme, hayal kurma, karar verme, sorun çözme becerilerinin; araştırma, bulma ve anlatma yeteneklerinin geliştiği gözlenmiştir. Araştırmanın kişisel gelişim teması ile ilgili bulguları empati kurmayı (Demircioğlu, 2010), problem çözme becerilerini (Özdemir ve Çakmak, 2008; Çakmakçı ve Özabac1, 2014; Palavan, 2017 ), hayal kurma (Gündoğan, Arı ve Gönen, 2014), hislerini ve düşüncelerini geliştirme (Başçı ve Gündoğdu, 2011; McCaslin, 1990; Ceylan, 2013; Genç, 2003), karar verme becerilerini karar verme mekânizmasını (Tate, 2005; Ceylan, 2013), yaratıc1lı yeteneklerini geliştirdiği (Yaffe, 1989; Nickerson, 2009), kendine güven duyma, özgüven ve öz yeterliliği (Morris, 2001; Ceylan, 2013; Tanrıseven ve Aykaç, 
2013), öz disiplini (Köksal Akyol, 2003), öz eleştiriyi (Akpınar Dellal ve Kara, 2010), kendini anlamayı (Köksal Akyol, 2003), kendini gerçekleştirmeyi (Özdemir ve Çakmak, 2008), çok boyutlu düşünmeyi (Akpınar Dellal ve Kara, 2010), eleştirel düşünmeyi (Yaffe, 1989; Yeğen, 2003; Arıkız, ve Beştepe, 2016) kazandırdığını ve geliştirdiğini vurgulayan araştıma sonuçları ile örtüşmektedir. Ancak bu çalışmada elde edilen "anlık cevap ve tepki (hazırcevaplılık)" bulgusu doğrudan kişilerin farklı olay ve durumlarla ilgili deneyim kazanma (McCaslin, 1990; Başçı ve Gündoğdu, 2011; Ceylan, 2013) birebir desteklemese de yakın ilişkili olarak düşünülebilir. Önceki çalışmalarda elde edilen bulgulardan farklı olarak "doğal davranma; sabır ve tahammül gösterme; bedensel gelişim ve aktiflik sağlama” sonuçlarına ulaşılmışır.

Değerler temasında da öğrencilerin eskisine göre birbirlerine daha çok saygı duydukları, daha demokratik davrandıkları, birbirlerine hoşgörü ve anlayış gösterdikleri, önyargısız davranmaya çalıştıkları insanları anlamak için çaba göstediklerini, bireysel ve kültürel farklılıklara saygı duydukları; gönüllülük ve paylaşma, saygı duyma gibi davranış ve değerleri belirttikleri gözlenmiştir. Çalışma sonunda ulaşılan bu sonuçlar; dramanın demokrasi fikrini (Aykaç ve Çetinkaya, 2013), hoşgörülü olmayı (Tanrıseven ve Aykaç, 2013), başkalarına saygı duymayı (Genç, 2003), kişilerin sorumluluk ve risk almayı (Köksal Akyol, 2003; Almaz ve diğerleri, 2014) olumlu yönde etkilediğini vurgulayan çalışmaların sonuçları ile benzerlik göstermektedir.

Yaratıcı drama etkinliklerinin öğrencilerin işbirliği, fikir alışverişi, paylaşma, yardımlaşma kaynaşma, yakınlaşma gibi sosyal özelliklerini geliştirdiği; öğrencilerin farklı insanlar (duygular, özellikler vb.) tanıdıklarını ve onların farklı1ıkları gördüklerini, samimiyet kazandıklarını; kişilere güven duyma davranışı gösterdiğini; paylaşım ve sosyalleşme yaşadıklarını; görev dağılımı ve paylaşımı ile birlikte karar alma süreçlerinde olumlu davranışlar kazandıkları ve bu etkinliklerin sınıf içi gruplaşmaları azalttığı gözlenmiştir. Bu sonuçlar drama ile ilgili yapılan çalışmalarda ortaya çıkan bireyin grubun parçası olması (Başçı ve Gündoğdu, 2011), sosyal etkileşimi artırması (Yassa 1997; Aykaç ve Çetinkaya, 2013), işbirliği ve birlikte çalışma yeteneği kazandırması (Abu Rass, 2010; Adıgüzel, 2013; Ceylan, 2013), bireyin sosyalleşmesini sağlaması (Aykaç ve Çetinkaya, 2013) ve sosyal becerileri kazandırması (Colston 1985; Önalan Akfırat, 2006; Kara ve Çam, 2007; Akpınar Dellal ve Kara, 2010; Namdar ve Çamadan, 2016)'1n bulgularıyla büyük ölçüde desteklenmektedir. Ayrıca bu çalışmada ortaya çıkan "rol kişisiyle özdeşim kurarak canlandırdığı farklı kişiliklerin yaşadığı duygularını yaşama" ulaşılabilen araştırmaların bulgularında gözlenememiştir.

Yine öğrencilerin öğretme-öğrenme sürecinde mutlu oldukları, eğlendikleri, derse katılmada istekli oldukları, kendilerini rahat hissetiklerini ve psikolojik ve bedensel rahatlama yaşadıkları; arkadaşlarıyla fiziksel temasta bulunabilmenin yarattığı duyguyu hissetikleri sonucu ortaya çıkmıştır. Yaratcı dramanın kişilere eğlenceli bir ortam yaratması, kişilerin bu ortamlarda kendilerini rahat hissetmesi, katılımı, istekliliği artırması bulguları alanyazında birçok çalışma tarafından vurgulanmıştır. Ancak bu çalışmanın sonunda katılımcıların "arkadaşlarıyla fiziksel temasta bulunabilmenin yarattığı duyguyu hissetme" sonucu farklı bir bulgu olarak ortaya çıkmış olup alanyazında gözlenememiştir. 


\section{Öneriler}

$\mathrm{Bu}$ çalışma ile ulaşılan sonuçlar doğrultsunda aşağıdaki önerilerde bulunulabilir:

- Drama dersi ve uygulamaları özellikle eğitim fakülteleri başta olmak üzere seçmeli dersler, çeşitli kurslar, öğrenci kulüp ve topluluklarının etkinlikleri vb. yoluyla öğretmen adayının kişisel gelişimi için kullanılabilir.

- Eğitim fakültesi ile birlikte yükseköğretimin tüm kurumlarındaki bireyler bütüncül gelişimleri için hem ders hem de öğretim yöntemi olarak yaratıcı dramadan yararlanmaya (akademik idari ve mali tedbirlerle) teşvik edilebilir.

- Özellikle öğretmen adaylarının mesleki, kişisel, sosyal, duygusal ve değer gelişimleri üzerindeki olumlu etkisi göz önüne alındığında, daha verimli olması açısından yaratıcı drama dersini verecek ya da bir yöntem olarak yaratıcı dramadan yararlanacak öğretim elemanlarının deneyimli olması daha nesnel sonuçlar ortaya koyabilir.

- Yükseköğretim birimlerinde ve özellikle eğitim fakültelerinde drama uygulamaları için uygun fiziki ortamlar oluşturulmalı ve düzenlenmelidir.

- Nitel araştırma yönteminin kullanıldığı bu çalışma kontrol gruplu nicel yöntemlerle farklı gruplarda belli sürelerde denenerek etki boyutunda çalışmalar yapılabilir. 


\section{Kaynakça}

Abu Rass, R. (2010). Drama in chalk and talk classrooms. Journal of Language Teaching and Research, 1(4), 378-381.

Adıgüzel, H. Ö. (2000). Eğitim bilimlerinde (Güzel sanatlar Eğitiminde) bir uzmanlık alanı olarak kültür pedagojisi. (Yayınlanmamış Doktora Tezi). Ankara Üniversitesi, Ankara

Adıgüzel, Ö. (2013). Eğitimde yaratıcı drama. (4 Baskı). Ankara: Pegem-A Yayıncılık.

Akoğuz, M. (2002). İletişsim becerilerinin geliş̧tirilmesinde yaratıcı dramanın etkisi. (Yayınlanmamış Yüksek Lisans Tezi). Ankara Üniversitesi, Ankara.

Akpınar Dellal, N. ve Kara, Z. (2010). Awareness levels of foreign language teacher candidates and teachers about drama techniques. Dil Dergisi, 149, 7-29.

Almaz, G., İşeri, K., ve Ünal, E. (2014). Research of the self-efficacy perceptions of teacher candidates towards the usage of creative drama method. International Journal of Languages' Education and Teaching, 2(3), 48-65.

Andersen, C. (2000), Process drama and classroom inquiry. Üçüncü Uluslararası Drama Eğitimi Araştırmaları Enstitüsü Sempozyumunda sunulmuş bildiri 21-25 Temmuz, Columbus, $\mathrm{OH}$

Annarella, L. A. (1992). Creative drama in the classroom. Washington D.C.: Office of Educational Research and Improvement

Arıkız, S., Beştepe, N . (2016). Tasarım sürecinde yaratıcılık "teknoloji ve tasarım dersinin yaratıcı drama yöntemiyle işlenmesi. Yaratıcı Drama Dergisi, 11(2), 47-64. DOI: 10.21612/yader.2016.011

Aya, Y , Günay, R , Aydın, H . (2016). Okul öncesi eğitimde drama yöntemi ile işlenen değerler eğitimi derslerinin farkındalık düzeyi üzerindeki etkisi. Sakarya University Journal of Education, 6(1), 23-37. DOI: http://dx.doi.org/10.19126/suje.76036

Aykaç, M. ve Çetinkaya, G. (2013). The effect of creative drama activities on pre-service Turkish language teachers' speaking skills. Turkish Studies- International Periodical for the Languages, Literature, and History of Turkish or Turkic, 8(9), 671-682. Doi :10.7827/TurkishStudies.5503

Aytaş, G. (2013). Eğitim ve öğretimde alternatif bir yöntem: Yaratıcı drama. Adiyaman Üniversitesi Sosyal Bilimler Enstitüsü Dergisi, 6(12), 35-54.

Başç, Z. ve Gündoğdu, K. (2011). The attitudes and opinions of prospective teachers related to dramacourses: The case of Atatürk University. Elementary Education Online, 10(2), 454-467.

Bütün, M., Tüzüner, A. , ve Duman, N . (2015). Coğrafya öğretmen adaylarının yaratıcı drama yöntemine ilişkin görüşleri. Yaratıcı Drama Dergisi, 10 (1), 1-14. DOI: 10.21612/yader.2015.001

Büyüköztürk, Ş., Kılıç-Çakmak, E., Akgün, Ö.E., Karadeniz, Ş. ve Demirel, F. (2010). Bilimsel Araştırma Yöntemleri, (6.Bask1). Ankara: Pegem Akademi Yayıncılık.

Ceylan, Ş. Y. (2013). Dramatik etkinlikler ve dramanın çocuğun gelişimindeki yeri. E. Ömeroğlu (Ed.), Okul öncesi eğitimde dramatik etkinliklerden dramaya teoriden uygulamaya (s. 17-43) içinde. Ankara: Eğiten Kitap Yayınc1lık

Colston, GL. (1985). The effects of a creative drama workshop and an arts on film program on the social interaction of deinstitutionalized developmentally disabledpersons (Therapeutic recreation, District of Columbia). PhD. Usa: University of Maryland Press.

Çakmakçı, E., ve Özabacı, N . (2014). Drama yolu ile karar verme becerilerinin kazandırılması. Elektronik Sosyal Bilimler Dergisi, 12 (44), 18-30.

Demir, K. (2012). "Sinıf ögretmeni adaylarına kırsal kesim sosyal yaşam becerilerini kazandırmada yaratıcı dramanın etkisi” Milli Eğitim Bakanlığı Özel Doğaç Yaratıcı Drama Eğitmenliği/Liderliği Bitirme Projesi. Ankara.

Demircioğlu, Ş. (2010). Teaching english vocabulary to young learners via drama. Procedia Social and Behavioral Sciences, 2(2), 439-443. https://doi.org/10.1016/j.sbspro.2010.03.039 
İnsan İlişkileri ve İletişim Dersinde Yaratıcı Drama Uygulamalarının Etkisine İlişkin Öğrenci Görüşleri

Dikici, H., Koç, M. ve Gündoğdu, R., (2003, Temmuz). Yaratıcı dramanın problem çözme becerilerine etkisi. (ÖZ).VII. Ulusal Psikolojik Danışma ve Rehberlik Kongresinde sunulan bildiri ( s. 107) içinde. Malatya. Erişim: https://issuu.com/antalyaozelegitimgrubu/docs/vii_ulusal_ps_koloj_k_dani_ma_re

Er, A. (2003). Drama ve dil öğretimi: Dramanın sözlü dil öğretimine etkisi. Kazım Karabekir Eğitim Fakültesi Dergisi, 8, 246-254

Ergin, A. ve Birol, C. (2000). Eğitimde Iletişim. Ankara: Anı Yayıcılık.

Fenli, A., Acar, V. ve Şahin, H. (2009, Ekim). Drama dersinin iletişim becerilerine katkısı (ÖZ). 18. Ulusal Eğitim Bilimleri Kongresinde sunulan sözlü bildiri. Ege Üniversitesi, İzmir. https://www.pegem.net/Akademi/bildiri_detay.aspx?id=101283

Genç, N. H. (2003). Yabancı dil öğretiminde öğretim tekniği olarak dramanın kullanımı ve bir örnek. Kazım Karabekir Eğitim Fakültesi Dergisi, 8, 267-276.

Gökçearslan Çifçi, E , Altınova, H .H. (2017). Sosyal hizmet eğitiminde yaratıcı drama yöntemiyle iletişim becerisi geliştirme: ders uygulaması örneği. Illkögrretim Online, 16 (4), 1384-1394. DOI: 10.17051/ilkonline.2017.342961

Gönen, M. ve Dalkılıç, N. (2000). Çocuk eğitiminde drama: Yöntem ve uygulamalar. İstanbul: Epsilon.

Gündoğan, A., Arı, M. ve Gönen, M. (2014). The Effect of Drama on the Creative Imagination of Children in Different Age Groups. Hacettepe Üniversitesi Eğitim Fakültesi Dergisi, 28(28-2), 206-220.

Hendy., L., Toon, L. (2001). Supporting drama and imaginative play in the early years. Open University Press, Hurd, B. M. (1991). Teach by the light of the moon, Science and Education. 31(2), 23-24

Kara, Y. ve Çam, F . (2007). Yaratıcı drama yönteminin bazı sosyal becerilerin kazandırılmasına etkisi. Hacettepe Üniversitesi Ĕgitim Fakültesi Dergisi, 32, 145-155.

Karasar, N. (2003). Bilimsel araştırma yöntemleri, (12.Baskı). Ankara: Nobel Yayıncılık.

Köksal Akyol, A. (2003). Drama ve dramanın önemi. Türk Eğitim Bilimleri Dergisi, 1(2), 179-190.

McCaslin, N. (1990). Creative drama in the classroom (5. Bask1.). Londra: Longman.

Merriam, S.B. (2013). Nitel Araştırma Desen ve Uygulama İçin Bir Rehber, (Çev.Editörü: Selahattin Turan). Ankara: Nobel Yayınları.

Metin G. G. (1999). Dramanın 5-6 yaş çocuklarının sosyal duygusal gelişimlerine etkisinin incelenmesi. M. $\ddot{U}$. Eğitim Bilimleri Enstitüsü. Istanbul

Morris, R. V. (2001). Drama and authentic assessment in a social studies classroom. Social Studies, 92 (1), 41-45.

Namdar, A. O. ve Çamadan, F. (2016). Yaratıcı drama uygulamalarının öğretmen adaylarınınsosyal becerilerine etkisi. Gazi Üniversitesi Ë̆itim Fakültesi Dergisi.36(3), 557-575

Nickerson, L. (2009). Science drama. School Science Review, 90 (332), 83-89.

Oğuz, A. ve Altun, E. (2011, Nisan) Öğretmen adaylarının yaratıcı dramaya yönelik tutumları ile empatik eğilim düzeyleri arasındaki ilişkinin incelenmesi. 2nd International Conference on New Trends in Education and Their Implications (s.1545-1552) içinde. Antalya. Erişim: http://iconte.org/FileUpload/ks59689/ File/269.pdf

Okvuran, A. (2000). Yaratıcı dramaya yönelik tutumlar. (Yayınlanmamış Doktora Tezi). Ankara Üniversitesi Sosyal Bilimler Enstitüsü, Ankara.

Önalan Akfirat, F . (2006). Sosyal yeterlilik, sosyal beceri ve yaratıcı drama. Yaratıcı Drama Dergisi, 1(1), 39-58

Özdemir, S. M. ve Çakmak, A. (2008). The effect of drama education on the prospective teachers' creativity. International Journal of Instruction, 1(1), 13-30.

Özşenler, D. (2013) Grup içi iletişimin etkinliğinde yaratıcı drama kullanımı ve kendini açma becerisi. (Yayımlanmamış Yüksek Lisans Tezi). Ege Üniversitesi Sosyal Bilimler Enstitüsü, İzmir 
Öztürk, A. (2001). Eğitim-öğretimde yeni bir yaklaşım: Yaratıcı drama. Kurgu Dergisi, 18, 251-259. Erişîm: http://hdl.handle.net/11421/1424

Palavan, Ö . (2017). Impact of drama education on the self-confidence and problem-solving skills of students of primary school education. Kastamonu Ĕ̈itim Dergisi, 25(1), 187-202.

Rances, J. N. (2005). Student perceptions of improving comprehension through drama as compared topeotry andfiction in college english freshman composition courses. (Yayınlanmamış Doktora Tezi). Widener University, Chester, $P A$

Rusilowski, J. A. (2017) Drama for developing integrity in Higher Education. Erişim: https://www.nature.com/ articles/palcomms201729 doi:10.1057/palcomms.2017.29

San, İ. (1990). Eğitimde yaratıı drama. Ankara Üniversitesi Eğitim Bilimleri Fakültesi Dergisi. 23(2), 573582.

San, İ. (2006). "Eğitimde yaratıcı drama" yaratıcı drama 1985-1998 yazılar. (Ed. H. Ömer Adıgüzel). Ankara: Naturel Yayınları.

Selimhocaoğlu, A. (2004, Temmuz). Drama ve ilkögretimde dramanın önemi (ÖZ). XIII. Ulusal Eğitim Bilimleri Kurultayında sunulan bildiri, Malatya ) Erişim: https://www.pegem.net/ Akademi/ bildiri_detay. aspx?id $=7843$

Tanrıseven, I. ve Aykaç, M. (2013). Opinions of the university students related to creative drama's contribution to their personal and professional lives. Adlyaman Üniversitesi Sosyal Bilimler Enstitüsü Dergisi, 6(12), 329-348.

Taşar, T. (2012) "Empati kurma becerisinin iletişime katkısının yaratıcı drama yöntemiyle işlenmesi" Milli Eğitim Bakanlığı Özel Doğaç Yaratıcı Drama Eğitmenliği / Liderliği Bitirme Projesi. Ankara.

Tate, K. J. (2005). A conceptual lens for observing, analyzing, and interpreting data when exploring preservice creative drama. Youth Theatre Journal, 19(1), 151-170.

Turner, H., Mayall, B., Dickinson, R., Clark, A., Hood, S., Samuels, J., ve Wiggings, M. (2004). Children engaging with drama: An evaluation of the National Theatre 's drama work in primary schools. London: Institute of Education, University of London.

Üstündağ, T. (1994). Günümüz eğitiminde dramanın yeri, Yassadkkça Eğitim Dergisis, 37,7-10

Üstündağ, T.(2006). Yaratıcı drama öğretmeninin günlüğ̈̈̈, Ankara: Pegem-A yayıncılık

Winston, J. (2002). Drama, spirituality and the curriculum. International Journal of Children's Spirituality, 7 (3), 241-255.

Yaffe, S. (1989). Drama as a teaching tool. Educational leadership, 46(6), 2935.

Yalın, H. İ. (2000). Öğretim teknolojileri ve materyal geliştirme. Ankara: Nobel Yayın Dağııım.

Yassa, N. A. (1997). A study of the effect of drama education on social interaction in high school students. Lakehead University, Ontario, Canada: Thunder Bay.

Yazar, A., Çelik, M., ve Kök, M. (2010). Okul öncesi eğitimde yaratıcı dramanın çocuğun gelişim alanlarına etkisi. Atatürk Üniversitesi Kazım Karabekir Eğitim Fakültesi Dergisi, 16, 15-21.

Yeğen, G. (2003). Yaratıcı drama. İlköğretim-Online Öğretim Uygulamaları Serisi, 2(2), 1-4.

Yılmaz, S. (2015). Sosyal bilgiler öğretiminde bir yöntem olarak dramanın kullanımına ilişkin öğretmen adaylarının görüşleri. Ahi Evran Üniversitesi Kırşehir Eğitim Fakültesi Dergisi, 14 (2), 123-145 